\title{
К вопросу о качестве интервьюирования клиентов в юридической клинике
}

\author{
Курчеева Ю.С., студент, \\ ФГБОУВО «Сибирский государственный \\ университет путей сообщения", \\ 2. Новосибирск \\ E-mail:pravo@stu.ru
}

Научный руководитель: зав. юридическим центром Колотыгина Н.Б.

При изучении теоретических курсов в юридических вузах студентов не обучают навыкам проведения беседы с клиентом. Для студентов-юристов очень важен практикум по консультированию и интервьюированию клиентов.

Результатом первой встречи с клиентом должно быть ясное понимание того, что ждет клиент, какую цель он хочет достигнуть в результате юридической консультации. Клиент нередко плохо представляет себе способы преодоления проблемы и юридические последствия. Клиент может сознательно или неумышленно вводить в заблуждение, или полагать, что какая-то информация неважна, или скрывать информацию, которая, по его мнению, порочит его в глазах студентов.

У начинающих юристов возникают следующие проблемы, «не умеет спрашивать», «не умеет слушать», «не умеет анализировать услышанное».

Нередко клиент в силу заболевания или возраста не всегда способен принимать обдуманное решение по своему делу. Поэтому юрист должен относиться к клиенту с вниманием и уважением, несмотря на возраст клиента, уровень культурного развития, национальности, темперамента, его поведения.

Отношения юриста и клиента должны быть сугубо деловыми, профессиональными и не более. Любое отклонение от этого правила может привести к конфликтной ситуации. Необходимо не забывать, что впечатление клиента о юристе и об организации начинает формироваться уже с того момента, как клиент переступил порог офиса. Именно это мнение - фундамент психологического контакта и доверительных отношений.

На практике опытные юристы обычно сразу чувствуют, что психологический контакт с клиентом не складывается, но у студентов этот навык еще не развит. Обычно и клиенты это чувствуют. В этом случае лучше всего прямо поговорить с клиентом, объяснить, что при таком отсутствии контакта им обоим будет очень сложно работать вместе. Попробовать самому юристу предпринять определенные усилия и попытаться установить должные отношения с клиентом и порекомендовать клиенту попытаться наладить контакт с юристом.

Казалось бы, интервьюирование клиента по своей сути сводится к задаванию клиенту вопросов и получению ответов, то есть к тому, чем каждый из нас занимается каждый день в обыденной жизни.

Юристу важно подготовить себя к встрече с клиентом, если эта встреча происходит впервые. Вариантами помех, которые могут помешать юристу правильно провести приём: озабоченность другими проблемами, скука, нетерпеливость. Эти факторы следует устранить, чтобы быть способным максимально быстро сосредоточиться на беседе с клиентом. 
Для того, чтобы юрист смог предложить варианты решения проблемы, ему необходимо провести исследование дела, что невозможно без проведения интервьюирования клиента, направленного на получение необходимой информации. На интервьюировании юристу необходимо получить от клиента информацию о том, какие обстоятельства прошлого и настоящего породили данную проблему. Юрист должен услышать первичную информацию из рассказа клиента. Рассказ посетителя помогает составить первое представление о тех событиях, которые привели клиента к юристу. Разные люди будут вести себя по-разному, излагая события. Опытный юрист должен управлять ходом свободного рассказа клиента, но прерывать и задавать вопросы торопиться не надо. Иначе можно навязать клиенту собственное представление о случившемся, упустить возможность уловить какие-то нюансы в деле, которые могут оказаться в дальнейшем не маловажными.

Часто бывают случаи, когда клиент не принес с собой необходимые документы, не помнит их содержание, сомневается о наличии у него их вообще. В этом случае надо решить, а имеет ли смысл вообще продолжать беседу и давать консультацию на основе имеющейся информации. В этом случае лучше назначить ещё одну дополнительную. встречу.

Очень часто молодые юристы опасаются показать свою неготовность дать консультацию сразу после интервьюирования. Это, якобы, показывает их непрофессионализм и некомпетентность. Это опасное заблуждение, которое может привести к даче некачественной консультации, так как опыт у молодого юриста ещё не большой, законодательство и судебная практика могли измениться. Клиент может настаивать на срочности ответа, но эту ситуацию можно отрегулировать пояснением о необходимости некоторых уточнений в свете последних имений в законодательстве.

Однако юристу мало знать то, что произошло у клиента. Никакая правовая помощь будет невозможна, если юристу не удастся выяснить интерес клиента. Понимание интереса клиента позволяет сформулировать цель, к достижению которого стремится клиент.

Задача юриста - суметь остаться объективным при сборе информации, чтобы в итоге выработать качественную позицию по делу, а также необходимо любому юристу чувство ответственности. Ошибочный совет может оказаться просто гибельным для клиента. Не надо спешить высказывать категоричные суждения. Осторожность избавит от ошибки и горьких упреков в некомпетентности. 